\title{
Analysis Of Causal Relationship Among GdP, Agricultural, Industrial AND Services Sector GROWTH IN TURKEY
}

Filiz YETIZ ${ }^{1}$

Cevher ÖZDEN ${ }^{2}$

\begin{abstract}
This paper investigates the causal relationship among GDP, agricultural, industrial and services sectors in Turkey for the period of 1968-2015. For this purpose, we employed Engle-Granger causality/block exogeneity Wald test, Impulse Response and Variance Decomposition analysis. The results showed unidirectional Granger causality from agriculture to GDP and the other three sectors, while the agricultural sector is not influenced by the others. This is an expected result for any developing country where the agriculture accounts for a large proportion of national GDP, but an unexpected result for developed countries like European Union members to which Turkey has long been wishing to join. To our knowledge, although this method has been applied in various areas, sectoral causality has not been studied for Turkey before.
\end{abstract}

Keywords: Causality, Granger, Agriculture, Impulse-Response, Variance Decomposition, GDP, Turkey.

\section{TÜrKIYY'DE GSYIH, TARIM, SANAYİ VE HizMETLER SEKTÖRLERI ARASINDAKİ NEDENSELLIK İLIŞKISISi}

Özet

Bu çalışmada, 1968-2015 yılları arasında Türkiye'nin GSYIH ile tarım, sanayi ve hizmetler sektörleri arasındaki nedensellik ilişsisi incelenmektedir. Bu amaçla, Engle-Granger nedensellik/Blok Dışsallık Wald testleri ile Etki-Tepki ve Varyans Ayrıştırma analizleri uygulanmıştır. Elde edilen sonuçlara göre, tarım sektöründen GSYIH, sanayi ve hizmetler sektörüne doğru tek yönlü granger nedenselliğin bulunduğu, ancak tarım sektörünün diğer sektörlerden etkilenmediğgi görülmüstür. Bu bulgu, halen GSYIH'n'nı önemli bir kismını tarım sektörünün oluşturduğu gelişmekte olan ülkeler için beklenen bir sonuçtur ancak Türkiye'nin uzun ylllardır tam üye olmak istediği AB Ülkeleri gibi sanayileşmiş ekonomilerde görülmesi beklenmez. Nedensellik analizi daha önce pek çok alanda uygulanmıș olmasına karșın, bilgimiz dahilinde sektörel nedensellik analizi Türkiye için daha önce gerçekleştirilmemiştir.

Anahtar Kelimeler: Nedensellik, Granger, Tarım, Etki-Tepki, Varyans Ayrıştırması, GSYïH, Türkiye.

\footnotetext{
${ }^{1}$ Asst.Prof.Dr., Nigde Ömer Halisdemir University, FEAS, Department of Banking and Finance, filiz.yetiz@ohu.edu.tr

${ }^{2}$ Dr., Çukurova University, Faculty of Agriculture, Department of Agricultural Economics, cozden@mgm.gov.tr
} 


\section{INTRODUCTION}

Agriculture is an important constituent of GDP and also contains a big part of work force in the developing countries. Agriculture can be an important source of growth by supporting other sectors through the transfer of resources, and providing a market for non-agricultural goods and services. On the other hand, agriculture can also take advantage of the technological improvements in the industry and services that spill over to agriculture. For developing counties, it is quite important to make wise allocation of sources among sectors to incite development. However, as the countries become industrialized, agriculture's relative importance in the economy starts to decrease. In Turkey, agriculture's share in GDP decreased from $22.5 \%$ in 1968 to $8.9 \%$ in 2015, and its share in total employment decreased from 46.5\% in 1988 to 20.5 in 2015 (TSI, 2016). The structure of agricultural supports and incentives in Turkey has undergone a substantial change in accordance with the industry-based development efforts, and obligations in the context of EU membership negotiation and WTO agreements (Arısoy, 2005). But, agriculture still holds its important position especially in the total employment of Turkey.

The aim of this paper is to investigate the interrelations between the three main sectors of Turkey's economy, namely the agriculture, industry and services, and determine whether agriculture has benefitted from and/or contributed to the expansion of the industry and services sector. For this purpose, we examined the relationships and causality among the three main sectors and GDP using a vector autoregression (VAR) model for the period 1968-2015. By using a VAR model, all variables are considered to be potentially endogenous, and we observed the short and long run responses to shocks and causality among the sectors.

\section{LITERATURE}

Tiwari (2011) examined the static and dynamic causality among sectoral incomes of agriculture, service and total GDP of India for the period 1950-51 to 2008-09, using Engle-Granger and Impulse-Response and Variance Decomposition analysis. Static causality analysis indicates that the service sector Granger causes industry sector and GDP and the agriculture sector Granger causes service sector. Dynamic causality results show that contribution to GDP forecast error by the industry sector is the highest, which is followed by agriculture and service sectors, while the contribution to the industry sector forecast error by GDP is the highest, which is followed by service sector and agriculture sector. In the case of service sector, explanation power of one standard deviation innovation in the industry and agriculture sectors to the forecast error variance is quite high $(30.6 \%$ and $40 \%$, respectively).

Rahman et al. (2011) examined the causal relationship among GDP, agricultural, industrial and service sector outputs for Bangladesh using the time series data from 1972 to 2008. They employed granger causality/block exogeneity Wald tests statistics in their study. They found a long run equilibrium relationship among these variables and bi-directional causality is observed between GDP and agriculture, industry and GDP, as well as between industry and service sectors. They also determined unidirectional granger causality from industrial sector to agricultural sector and GDP to service sector. Their results indicate that agricultural and industrial sectors are driving factors of the GDP in Bangladesh and the reverse is also true. On the other hand, service sector does not influence the GDP but GDP influences the growth of the service sector.

Gülistan et al. (2008) examined the causal relationship between primary energy consumption (EC) and real Gross National Product (GNP) for Turkey for 1970-2006, employing unit root test, Augmented Dickey-Fuller (ADF), Phillips-Perron (PP), Johansen co-integration test and Pair-wise Granger causality tests. Their results indicate that two series are cointegrated and there is a bidirectional causality from EC to GNP and vice versa, which means that an increase in EC directly 
affects economic growth and also economic growth stimulates further EC. They concluded that energy is a limiting factor to economic growth in Turkey and thus, shocks to energy supply will have a negative impact on economic growth.

Liela and Talar (2012) investigated the dynamic causal relationship between energy consumption and economic growth in Lebanon over the period of 1980-2009. They employed various causality tests including Hsiao, Toda-Yamamoto and vector error correction based granger causality tests. In conclusion, they determined bidirectional relationship both in the short and long run, indicating that energy is a limiting factor to economic growth in Lebanon.

Adenomon and Oyejola (2013) investigated the impact of agriculture and industry on GDP in Nigeria for the period of 1960-2011, employing VAR and SVAR models. The results of VAR model indicated that agriculture contributed about $58 \%$ to GDP, while industry contributed about $32 \%$. On the other hand, the results of SVAR model revealed that agriculture and industry contributed to the structural innovations of GDP in Nigeria, with more contribution resulting from agriculture sector. In conclusion, they recommended that special incentives should be given to agriculture sector and infrastructural facilities to boost the development, while new approaches should also be pursued for industry sector.

Siboleka et al. (2014) investigated whether or not there is a causal and long term relationship between agriculture and manufacturing sectors of Namibia over the period 1981-2012. They used unit root, correlation and granger causality tests and determined no causal relationship between agriculture and manufacturing in Namibia, and claimed that appropriate policy interventions are required to influence how the two sectors should benefit from each other in order to support potentials for both sustained employment opportunities and economic growth in Namibia.

Gaspar et al. (2015) investigated the long run relationship and causality among agriculture, industry and service sectors of Portugal for the period of1970-2006, estimating a trivariate VAR model in terms of both value added and productivity of the sectors. As a result, they determined that agriculture value added is both weakly and strongly exogenous and exerted no influence on the other two sectors, nor was it affected by them. This is a normal and expected result for the developed countries since agriculture accounts only a small fraction of total GDP and employment. Turkey wants to join EU for a long time, and currently pursuing a full membership negotiation. However, it is a question for both EU and Turkey whether Turkey's economic structure is really ready for common agricultural policy of EU. Agriculture still accounts for 8-10\% of total GDP and about 25\% of employment, which probably does not take into account disguised unemployment correctly. However, agriculture constitutes $1.7 \%$ of total GDP in EU-28 combined, and this rate changes between 1-3\% for individual counties (Narin, 2011; Temiz and Gökmen, 2010). From employment respect, agriculture accounts for 5.7\% of total employment in EU-28 combined, and it changes mostly around $4-5 \%$, only increases to $37 \%$ in Romania, $13 \%$ in Portugal and $18 \%$ in Greece (Eurostat, 2016).

\section{MATERIAL AND METHODS}

Annual data of GDP and constituent sectors for the period of 1968-2015 were used in the study. Data were obtained from Turkish Statistical Institute (TSI) in two different series based on 1987 prices and 1998 prices. Different inflators were formulated for each sector using the data pertaining to the period of 1998-2006 covered by both series. Then, two series were combined by these inflators. Agriculture sector comprises agriculture and livestock production, forestry and fishing; industry comprises mining and quarrying, manufacturing, electricity, gas and water, construction, wholesale and retail trade; and services sector comprises services of hotels and restaurants, transportation and communication, financial institution, ownership of dwellings, business and personal services, imputed bank services, government services and private non-profit institutions. 
Stationary property of the data series have to be checked in order to prevent biased conclusions in the study. For this purpose, Augmented Dickey-Fuller (ADF) unit root test was used to check stationarity (Yetiz, 2008; Rahman et al., 2011).

$$
\begin{gathered}
\Delta X_{t}=\mu+\alpha t+\delta X_{t-1}+\sum \delta i \Delta X_{t}-1+\varepsilon_{t} \\
\Delta X_{t}=X_{t}-X_{t-1}
\end{gathered}
$$

$\mathrm{X}_{\mathrm{t}}$ : dependent variable

$\mu$ : constant

$\mathrm{t}:$ trend

$\varepsilon_{\mathrm{t}}:$ stochastic error

$\mathrm{H}_{0}: \delta=0\left(\mathrm{X}_{\mathrm{t}}\right.$ is non-stationary)

$\mathrm{H}_{\mathrm{A}}: \delta \neq 0\left(\mathrm{X}_{\mathrm{t}}\right.$ is stationary)

In the next step, Johansen Cointegration test was used to determine possible cointegration relationship among data. In this model, the cointegration relationship is shown as below, and if the error term is stationary $\mathrm{I}(0)$, two series is concluded cointegrated.

$$
Y_{t}=\beta X_{t}+\varepsilon_{t}
$$

$$
\begin{aligned}
& H_{0}: \beta=0 \text { (series are not cointegrated) } \\
& H_{\mathrm{A}}: \beta \neq 0 \text { (series are cointegrated) }
\end{aligned}
$$

The rejection of null hypothesis $\mathrm{H}_{0}$ indicates the cointegration of series, which means that the series take joint action in the long run. However, this test does not reveal the direction of the relationship. One method that can be used for this purpose is Granger causality test. In order to test for Granger causality, we will estimate a VAR model as follows, in which all variables are initially considered symmetrically and endogenously (Rahman et al., 2011; Gaspar et al., 2015).

$$
\begin{aligned}
& Y_{t}=a_{0}+a_{1} Y_{t-1}+\cdots+a_{p} Y_{t-p}+b_{1} X_{t-1}+\cdots+b_{p} X_{t-p}+\mu_{t} \\
& X_{t}=c_{0}+c_{1} X_{t-1}+\cdots+c_{p} X_{t-p}+d_{1} Y_{t-1}+\cdots+d_{p} Y_{t-p}+v_{t}
\end{aligned}
$$

Here, testing $\mathrm{H}_{0}: \mathrm{b}_{1}=\mathrm{b}_{2}=\ldots . .=\mathrm{b}_{\mathrm{p}}=0$, against $\mathrm{H}_{\mathrm{A}}$ : 'Not $\mathrm{H}_{0}$ ', is a test that $\mathrm{X}$ does not Grangercause $\mathrm{Y}$. Similarly, testing $\mathrm{H}_{0}: \mathrm{d}_{1}=\mathrm{d}_{2}=\ldots . .=\mathrm{d}_{\mathrm{p}}=0$, against $\mathrm{H}_{\mathrm{A}}$ : 'Not $\mathrm{H}_{0}$ ', is a test that $\mathrm{Y}$ does not Granger-cause X. In each case, a rejection of the null implies there is Granger causality.

\section{FINDINGS, RESULTS AND DISCUSSION}

Annual data of GDP and constituent sectors for the period of 1968-2015 were used for estimation. Initially, data were transformed into their natural logarithms to account for the expected non-linearity in the relationship and test for stationarity in variance. The summary statistics of each variable are given in the Table 1 and trend graphs are given in Figure 1. 
Figure 1. Trend values of logged agriculture (LAG), GDP (LGP), industry (LIN) and Services (LSE)

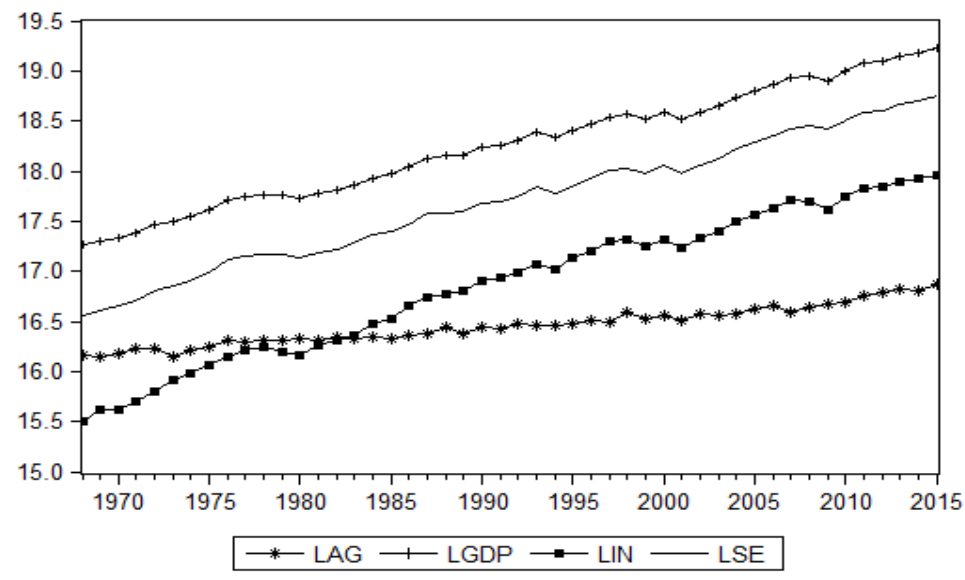

Table 1. The summary statistics of LGDP, LAG, LIN and LSE

\begin{tabular}{lcccc}
\hline & LAG & LGP & LIN & LSE \\
\hline Mean & 16.455 & 18.254 & 16.861 & 17.692 \\
Median & 16.453 & 18.280 & 16.960 & 17.721 \\
Maximum & 16.872 & 19.224 & 17.958 & 18.752 \\
Minimum & 16.149 & 17.263 & 15.506 & 16.560 \\
Std. Dev. & 0.190 & 0.571 & 0.721 & 0.628 \\
Skewness & 0.320 & -0.022 & -0.213 & -0.067 \\
Kurtosis & 2.294 & 1.876 & 1.859 & 1.933 \\
Jarque-Bera & 1.817 & 2.532 & 2.966 & 2.314 \\
Probability & 0.403 & 0.282 & 0.227 & 0.314 \\
Observations & 48 & 48 & 48 & 48 \\
\hline
\end{tabular}

From Table 1, the mean returns of LAG, LGP, LIN and LSE are 16.455, 18.254, 16.861 and 17.692, respectively. The ranges of standard deviation of the same series change from 0.190 to 0.721 . From Figure 1, it is seen that the series of GDP, industry and service sectors has increased faster than the series of agriculture in Turkey's case, and all the series seem to be not stationary. As already known, stationary time series tend to return its mean value and fluctuate around it with a constant range. On the other hand, a non-stationary variable becomes stationary after it is differenced, in which case the first order differencing mostly suffices. Stationary of a variable depends on whether it has a unit root or not. In the Table 2, the results of unit root test obtained using Augmented Dickey-Fuller (ADF) are given for both level and first difference of the series. 
Table 2. Augmented Dickey-Fuller Test Results of Variables in Level and First Difference

\begin{tabular}{llll}
\hline & $\begin{array}{l}\text { ADF } \\
\text { t-statistics }\end{array}$ & prob. & Result \\
\hline LAG & 4.254 & 1.000 & Non-stationary \\
LGP & 7.046 & 1.000 & Non-stationary \\
LIN & 6.422 & 1.000 & Non-stationary \\
LSE & 7.110 & 1.000 & Non-stationary \\
DLAG & -4.075 & 0.000 & Stationary \\
DLGP & -2.276 & 0.024 & Stationary \\
DLIN & -4.150 & 0.000 & Stationary \\
DLSE* & -7.487 & 0.000 & Stationary \\
\hline
\end{tabular}

*Intercept was chosen as deterministic regressor for DLSE, while none was selected for the other. All the first difference ADF regressions have a significant unit root coefficient at $5 \%$ and $1 \%$ levels. * refers to the first difference.

From Table 2, the null hypothesis that the series are non-stationary is not rejected at levels for all variables. However, after taking their first differences, the null hypothesis is rejected for all variables, in which case the series becomes stationary and variables are integrated at order one I(1).

After questioning the stationarity of the variables, the next step is to apply Johansen cointegration test, which requires the existence of sufficient number of time lags. The optimum lag lengths are determined using LR, FPE, Akaike, Schwarz and Hannan-Quinn information criteria. And the second test of deterministic trend assumption (intercept no trend in CE- no intercept in VAR) was chosen according to Log Likelihood, Akaike Information Criteria and Schwarz Criteria. Then, the Johansen Co-Integration test was applied using model 2 and lag interval $(1,4)$. Test results are given in Table 3.

Table 3. Cointegration Test Results

\begin{tabular}{|c|c|c|c|c|}
\hline \multicolumn{5}{|c|}{ Sample (adjusted): 1974 - 2015} \\
\hline \multicolumn{5}{|c|}{ Included observations: 42 after adjustments } \\
\hline \multicolumn{5}{|c|}{ Trend assumption: No deterministic trend (restricted constant) } \\
\hline \multicolumn{5}{|c|}{ Series: DLGP, DLIN, DLSE, DLAG } \\
\hline \multicolumn{5}{|c|}{ Lags interval (in first differences): 1 to 4} \\
\hline \multicolumn{5}{|c|}{ Unrestricted Cointegration Rank Test (Trace) } \\
\hline Hypothesized & & Trace & 0.05 & \\
\hline No. of CE(s) & Eigenvalue & Statistic & Critical Value & Prob.** \\
\hline None $*$ & 0.574419 & 62.10211 & 54.07904 & 0.0082 \\
\hline At most 1 & 0.288848 & 26.22152 & 35.19275 & 0.3297 \\
\hline At most 2 & 0.185091 & 11.90500 & 20.26184 & 0.4573 \\
\hline At most 3 & 0.075751 & 3.308489 & 9.164546 & 0.5247 \\
\hline \multicolumn{5}{|c|}{ Trace test indicates 1 cointegrating eqn(s) at the 0.05 level } \\
\hline \multicolumn{5}{|c|}{$*$ denotes rejection of the hypothesis at the 0.05 level } \\
\hline \multicolumn{5}{|c|}{ **MacKinnon-Haug-Michelis (1999) p-values } \\
\hline \multicolumn{5}{|c|}{ Unrestricted Cointegration Rank Test (Maximum Eigenvalue) } \\
\hline Hypothesized & & Max-Eigen & 0.05 & \\
\hline
\end{tabular}




\begin{tabular}{|l|l|l|l|l|}
\hline No. of CE(s) & Eigenvalue & Statistic & Critical Value & Prob.** \\
\hline None $*$ & 0.574419 & 35.88060 & 28.58808 & 0.0049 \\
\hline At most 1 & 0.288848 & 14.31652 & 22.29962 & 0.4335 \\
\hline At most 2 & 0.185091 & 8.596509 & 15.89210 & 0.4782 \\
\hline At most 3 & 0.075751 & 3.308489 & 9.164546 & 0.5247 \\
\hline Max-eigenvalue test indicates 1 cointegrating eqn(s) at the 0.05 level \\
\hline * denotes rejection of the hypothesis at the 0.05 level \\
\hline **MacKinnon-Haug-Michelis (1999) p-values \\
\hline
\end{tabular}

Both Trace and Eigenvalue statistics indicate that there is at least 1 co-integrating equation at $1 \%$ significance level. Therefore, the results of Johansen co-integration test show a long-running association among sectoral and GDP series. In the next step, we applied Granger Causality Wald Test and the results are given in Table 4.

Table 4. Engle-Granger Causality Analysis

\begin{tabular}{|l|l|l|l|l|}
\hline \multicolumn{5}{|l|}{ VAR Granger Causality/Block Exogeneity Wald Tests } \\
\hline \multicolumn{5}{|l|}{ Sample: 1968 - 2015 } \\
\hline \multicolumn{5}{|l|}{ Included observations: 43 } \\
$\begin{array}{l}\text { Dependent } \\
\text { Variable }\end{array}$ & Excluded & Chi-sq & df & Prob. \\
\hline DLGP & DLIN & 4.578328 & 4 & 0.3334 \\
\hline & DLSE & 3.186677 & 4 & 0.5271 \\
\hline & DLAG & 17.75711 & 4 & 0.0014 \\
\hline DLIN & DLGP & 6.087797 & 4 & 0.1927 \\
\hline & DLSE & 4.677662 & 4 & 0.3220 \\
\hline & DLAG & 17.41588 & 4 & 0.0016 \\
\hline DLSE & DLGP & 1.186407 & 4 & 0.8803 \\
\hline & DLIN & 4.580997 & 4 & 0.3331 \\
\hline & DLAG & 14.89889 & 4 & 0.0049 \\
\hline DLAG & DLGP & 4.107324 & 4 & 0.3917 \\
\hline & DLIN & 4.228688 & 4 & 0.3759 \\
\hline & DLSE & 3.491675 & 4 & 0.4791 \\
\hline
\end{tabular}

From Table 4, it is evident that DLAG (agriculture) is granger cause to DLGDP (GDP), DLIN (Industry) and DLSE (services), while the reverse is not true. DLGDP, DLIN and DLSE are not granger cause to DLAG. To explore the dynamic features of the series, Impulse Response Functions (IRFs) are computed. IRFs show the impact of a shock in an exogenous variable upon endogenous variable over a period of time (20 years in present study).

From Figure 2 below, we found the evidences from the impulse response analysis on the convergent and divergent influence of the agricultural, industrial and service sector from one time shock on GDP. Accordingly, services, industry and GDP respond to the change in agriculture, and this effect diminishes only after 8 years. 
Figure 2. Impulse response analysis for different variables
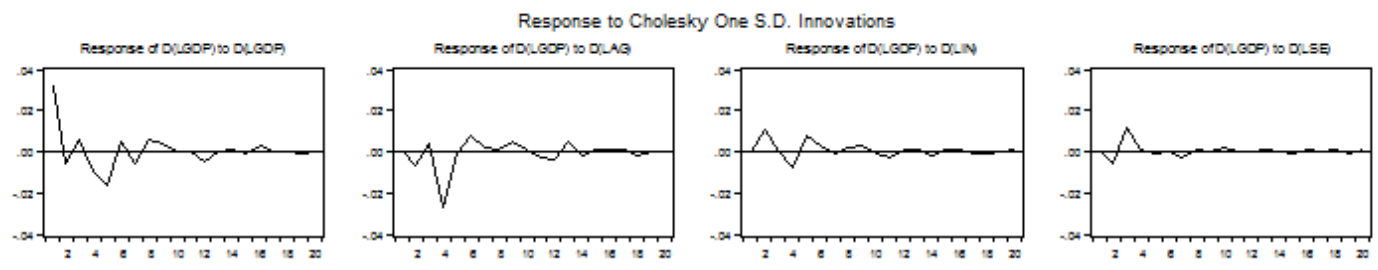

Fesporse GTDLAG wo DLGO

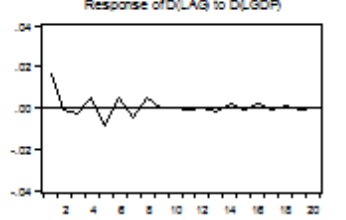

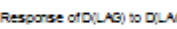

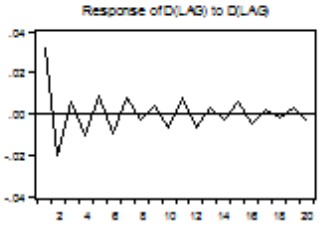

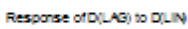

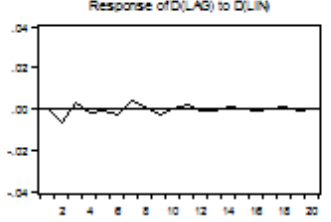

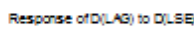

Fesporse otolun to DLGOP

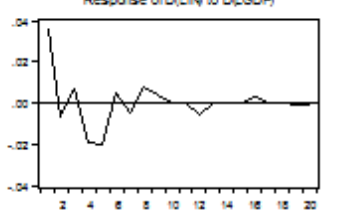

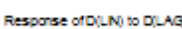

Resporse or DLN TODLIN
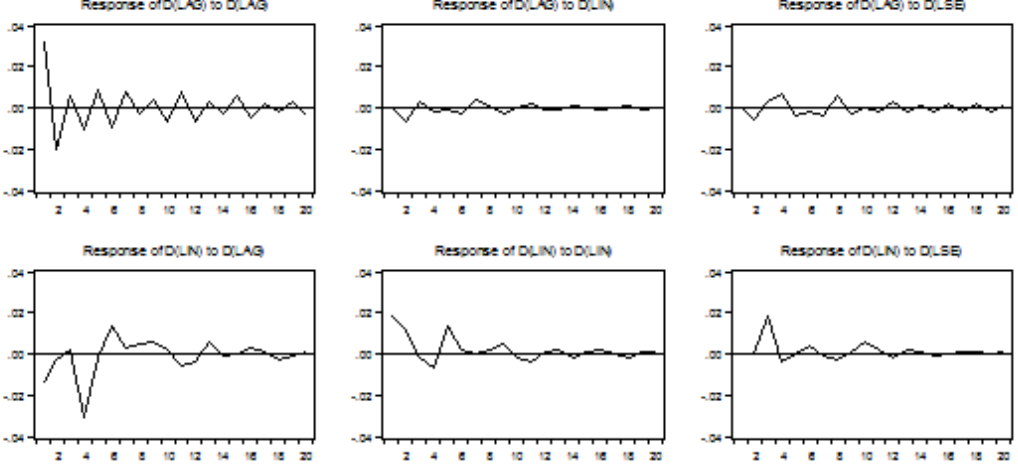

Resporse OHOLSE 10 DLGO

Fesorse OtOLISE) wO DLAG
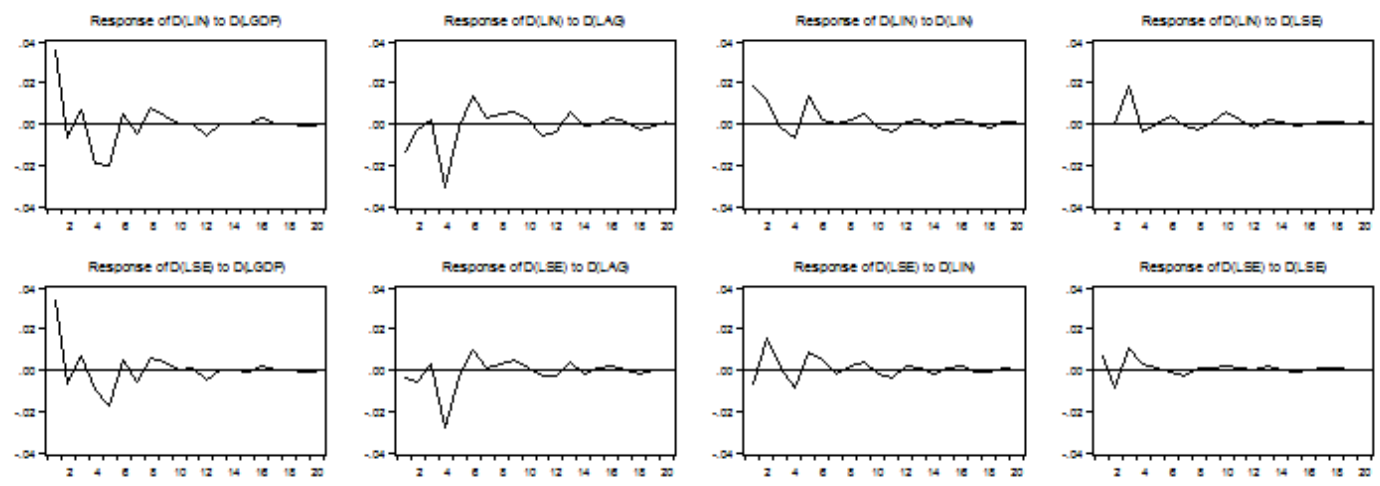

In the next step, we performed variance decomposition to understand the extent of effects. In this analysis, it would be more convenient to consider the 8th period since the shock effects subside in this period (Evlimoglu and Condur, 2012). Accordingly, GDP is explained $54.06 \%$ by itself, $31.05 \%$ by agriculture, $8.53 \%$ by industry and $6.36 \%$ by services sectors. Agriculture is explained mostly by itself throughout the period. Industry is explained $47.57 \%$ by GDP, $29.28 \%$ by agriculture, $15.90 \%$ by itself and $8.24 \%$ by services sectors. Lastly, services sector is explained $50.01 \%$ by GDP, $28.63 \%$ by agriculture, $14.28 \%$ by industry and $7.40 \%$ by itself. These figures support the results of granger causality analysis.

Table 5. Variance Decomposition

\begin{tabular}{|c|c|c|c|c|c|}
\hline \multicolumn{6}{|c|}{ Variance Decomposition of D(LGP): } \\
\hline Period & S.E. & $\mathrm{D}(\mathrm{LGP})$ & $\mathrm{D}(\mathrm{LAG})$ & $\mathrm{D}(\mathrm{LIN})$ & $\mathrm{D}(\mathrm{LSE})$ \\
\hline 1 & 0.031844 & 100.0000 & 0.000000 & 0.000000 & 0.000000 \\
\hline 2 & 0.035151 & 84.60520 & 3.389846 & 9.148871 & 2.856086 \\
\hline 3 & 0.037568 & 76.29706 & 3.984482 & 8.023014 & 11.69545 \\
\hline 4 & 0.048108 & 50.38933 & 34.93335 & 7.458114 & 7.219205 \\
\hline 5 & 0.051510 & 54.38011 & 30.51333 & 8.739211 & 6.367345 \\
\hline 6 & 0.052436 & 53.34884 & 31.80296 & 8.703533 & 6.144664 \\
\hline 7 & 0.052844 & 53.53591 & 31.44735 & 8.586939 & 6.429797 \\
\hline 8 & 0.053243 & 54.05891 & 31.04526 & 8.534801 & 6.361031 \\
\hline 9 & 0.053674 & 53.64881 & 31.38571 & 8.704886 & 6.260594 \\
\hline \multicolumn{6}{|c|}{ Variance Decomposition of D(LAG): } \\
\hline Period & S.E. & $\mathrm{D}(\mathrm{LGP})$ & $\mathrm{D}(\mathrm{LAG})$ & $\mathrm{D}(\mathrm{LIN})$ & $\mathrm{D}(\mathrm{LSE})$ \\
\hline 1 & 0.035842 & 21.57657 & 78.42343 & 0.000000 & 0.000000 \\
\hline 2 & 0.041941 & 15.83494 & 79.66956 & 2.711050 & 1.784448 \\
\hline 3 & 0.042551 & 15.76549 & 79.05328 & 3.086698 & 2.094537 \\
\hline 4 & 0.044745 & 15.22877 & 77.37119 & 2.993051 & 4.406990 \\
\hline
\end{tabular}




\begin{tabular}{|c|c|c|c|c|c|}
\hline 5 & 0.046574 & 17.51470 & 74.97685 & 2.785525 & 4.722918 \\
\hline 6 & 0.047975 & 17.42655 & 74.93445 & 3.089416 & 4.549581 \\
\hline 7 & 0.049111 & 17.62993 & 73.69302 & 3.701757 & 4.975295 \\
\hline 8 & 0.049828 & 18.20903 & 71.86293 & 3.663435 & 6.264604 \\
\hline 9 & 0.050137 & 17.98744 & 71.52323 & 3.948710 & 6.540622 \\
\hline 10 & 0.050639 & 17.63440 & 72.08117 & 3.872379 & 6.412054 \\
\hline \multicolumn{6}{|c|}{ Variance Decomposition of D(LIN): } \\
\hline Period & S.E. & $\mathrm{D}(\mathrm{LGP})$ & $\mathrm{D}(\mathrm{LAG})$ & $\mathrm{D}(\mathrm{LIN})$ & $\mathrm{D}(\mathrm{LSE})$ \\
\hline 1 & 0.042250 & 71.87145 & 10.14208 & 17.98647 & 0.000000 \\
\hline 2 & 0.044492 & 67.25961 & 9.634178 & 23.10480 & 0.001415 \\
\hline 3 & 0.048788 & 57.66530 & 8.237406 & 19.35868 & 14.73861 \\
\hline 4 & 0.061394 & 46.04640 & 30.82849 & 13.41727 & 9.707840 \\
\hline 5 & 0.066119 & 48.93667 & 26.70537 & 15.98519 & 8.372768 \\
\hline 6 & 0.067810 & 47.06046 & 29.37890 & 15.25947 & 8.301164 \\
\hline 7 & 0.068058 & 47.18353 & 29.40528 & 15.15128 & 8.259912 \\
\hline 8 & 0.068743 & 47.56982 & 29.28572 & 14.90184 & 8.242612 \\
\hline 9 & 0.069249 & 47.26682 & 29.48042 & 15.09287 & 8.159877 \\
\hline \multicolumn{6}{|c|}{ Variance Decomposition of D(LSE): } \\
\hline Period & S.E. & $\mathrm{D}(\mathrm{LGP})$ & $\mathrm{D}(\mathrm{LAG})$ & $\mathrm{D}(\mathrm{LIN})$ & $\mathrm{D}(\mathrm{LSE})$ \\
\hline 1 & 0.035212 & 90.67944 & 1.170841 & 4.031349 & 4.118370 \\
\hline 2 & 0.040273 & 71.79751 & 2.982797 & 17.87226 & 7.347435 \\
\hline 3 & 0.042291 & 67.45432 & 3.325386 & 16.28819 & 12.93211 \\
\hline 4 & 0.052589 & 46.94715 & 30.91218 & 13.51353 & 8.627139 \\
\hline 5 & 0.056305 & 50.93155 & 27.36587 & 14.11472 & 7.587853 \\
\hline 6 & 0.057451 & 49.50634 & 28.97410 & 14.19110 & 7.328462 \\
\hline 7 & 0.057847 & 49.77636 & 28.59553 & 14.08298 & 7.545140 \\
\hline 8 & 0.058211 & 50.01499 & 28.48611 & 14.00331 & 7.495593 \\
\hline 9 & 0.058672 & 49.69821 & 28.62691 & 14.27893 & 7.395948 \\
\hline 10 & 0.058743 & 49.57865 & 28.61691 & 14.32526 & 7.479175 \\
\hline \multicolumn{6}{|c|}{ Cholesky Ordering: D(LGP) D(LAG) D(LIN) D(LSE) } \\
\hline
\end{tabular}

\section{CONCLUSION}

This study investigated the causal relationship among GDP, agriculture, industry and services sectors in Turkey for the period of 1968-2015. A long run equilibrium relationship was found among these variables. And, to further examine the nature of the relationship, granger causality/block exogeneity Wald test was applied and a uni-directional relationship was detected from agriculture to GDP and the other sectors, which indicates that agriculture incites the growth of other sectors, while it is not affected by the others. Turkey's agriculture sector made a more significant contribution to GDP than it does today. Especially, from the late 1980s onwards, successive governments have tried to follow a mixed, yet rather industry-based development course, and as a result, agriculture's share in GDP has decreased from 33.5\% in 1968 to $8.9 \%$ in 2015, which shows that the importance of this sector has shifted to the other main sectors of Turkey's economy and contributed to their growth, as well.

\section{REFERENCES}

Adenomon, M. O., Oyejola, B. A. (2013). Impact of Agriculture and Industrialization on GDP in Nigeria: Evidence from VAR and SVAR Models. International Journal of Analysis and Applications, 1, 1, 40-78. 
Arısoy İ. (2005). Industrial Development in Turkey in terms of Industrialization and Main Indicators, Cukurova University, Journal of Social Sciences Institute, 14, 1.

Dagher, L., Yacoubian, T. (2012). The Casual Relationship between Energy Consumption and Economic Growth in Lebanon. Energy Policy, 50 (2015), 795-801.

Eurostat, (2016). European Statistics, National Accounts Database, http://ec.europa.eu/eurostat/ data/database

Evrimoğlu U., Çondur, F. (2012). An Analysis of Interlinkages between The IMKB and the Shock Exchange Markets of Developed and Developing Countries for Pre- and Post-Crisis Periods, Uludag Journal of Economy and Society, 16, 1.

Gaspar, J., Gilson, P., Simoes, M. C. N. (2015). Agriculture in Portugal: Linkages with industry and services. Faculdade de Economica da Universidaded de Coimbra.

Gülistan Erdal, Hilmi Erdal, Kemal Esengün, 2008. The causality between energy consumption and economic growth in Turkey. Energy Policy, 36 (2008) 3838-3842.

Mostafizur Rahman, Sayedur Rahman and Wu Hai-bing, 2011. Time Series Analysis of Causal Relationship among GDP, Agricultural, Industrial and Service Sector Growth in Bangladesh. China-USA Business Review, 10 (2011), 1, 9-15.

Narin, M. (2011). Change in the Agricultural Support Policies implemented in Turkey, Journal of Economic Approach, 19, 183-225.

Siboleka, M., Nyambe, J. M., Osterkamp, R.(2014). Agriculture and Manufacturing Sector Growth in Namibia during the 1981 to 2012: A Granger Causality Test. British Journal of Economics, Management\&Trade, 4(11):1700-1707.

Temiz, D., Gökmen, A.(2010). An Analysis of the Export and Economic Growth in Turkey over the period of 1950-2009. International Journal of Economic and Administrative Studies, 5, 5.

Tiwari, A. (2011). Relationship between Industry, Agriculture, Service Sectors and GDP: The Indian Experience. International Journal of Economics and Business, 1(2010), 1.

TSI, (2016). Turkish Statistical Institute, National Accounts and Employment Databases. http:// www.turkstat.gov.tr/UstMenu.do?metod=kategorist

Yetiz, F. (2008). Structure of the Financial System, Relationship between Financial Depth and Economic Growth, Turkish Finance System, Cukurova University, Department of Economy, Master Thesis. 